\title{
Applying Chemometric Techniques to Biogenic Substances as a Source of Pollution in Lake Surface Waters
}

\author{
Anna Bucior-Kwaczyńska* \\ Department of Chemistry and Natural Waters Management, Institute for Research on Biodiversity, Faculty of Biology, \\ Szczecin University, Szczecin, Poland
}

Received: 24 April 2019

Accepted: 23 June 2019

\begin{abstract}
During spring 2008 and 2013, the concentrations of nitrogen substances $\left(\mathrm{NO}_{3}^{-}, \mathrm{NO}_{2}^{-}\right.$and $\left.\mathrm{NH}_{4}^{+}\right)$ were investigated against the background of changes in other selected physical and chemical water quality indices in the surface waters of Lake Warnowo located in Wolin National Park on Volin Island. It was found that the investigated waters were additionally contaminated by nitrogen compounds. This is illustrated by increased values of $\mathrm{NO}_{3}^{-}, \mathrm{NO}_{2}{ }^{-}$and $\mathrm{NH}_{4}{ }^{+}$concentrations of the investigated waters in 2013 to max. values $0,28\left(\mathrm{~N}-\mathrm{NO}_{3} / \mathrm{dm}^{3}\right), 0,103\left(\mathrm{~N}-\mathrm{NO}_{2} / \mathrm{dm}^{3}\right)$ and $0,34\left(\mathrm{~N}-\mathrm{NH}_{4} / \mathrm{dm}^{3}\right)$, causing water quality deterioration in the lake by one class of quality compared to 2008 (where the max. values amounted to $0,39\left(\mathrm{~N}-\mathrm{NO}_{3} / \mathrm{dm}^{3}\right), 0,016\left(\mathrm{~N}-\mathrm{NO}_{2} / \mathrm{dm}^{3}\right)$ and $0,13\left(\mathrm{~N}-\mathrm{NH}_{4} / \mathrm{dm}^{3}\right)$, which led to accelerated water eutrophication in the lake in 2008-2013. This paper performs one of the chemometric techniques - principal component analysis (PCA) - used to classify water quality indices.
\end{abstract}

Keywords: PCA, nitrogen compounds, eutrophication, water pollution, water quality

\section{Introduction}

Water, which is one of the main elements of the natural environment and occupies about $75 \%$ of the earth surface, is used in every area of human life. It is used not only for living purposes, but also in agriculture, industry and transport.

Natural water, mainly surface water, is exposed to numerous contaminants. These pollutants have become an increasing threat to human society and natural

*e-mail: aniabucior@wp.pl, anna.bucior@usz.edu.pl ecosystems in recent decades [1]. Frequently, although not the most important, sources of pollution of natural waters are thermal inflows and precipitations [2-4]. Very often effluents from farms, allotment gardens and communal and industrial sewage [5-8] wastewater are discharged into surface water [9]. Also, fertilizers used in agriculture are one of the main sources of water pollution, mainly by nitrogen-containing compounds [10]. This leads to an increase in concentrations of nitrogen compounds $\left(\mathrm{NO}_{3}^{-}, \mathrm{NO}_{2}^{-}\right.$and $\left.\mathrm{NH}_{4}^{+}\right)$in water reservoirs and adjacent areas. At the same time, nitrogen compounds are essential for the development of living organisms, and their presence in the aquatic environment determines the state of the ecosystem [11, 12]. 
The consequence of excessive nitrogen compounds in the ecosystem is excessive, uncontrolled development of phytoplankton and aquatic vegetation $[13,14]$ leading to faster eutrophication of the water reservoir.

Thus, water bodies very often serve as temporary or final receptors of a diverse variety of contaminants, which consequently cause the water to become toxic. The rapid stride in industrialization is a major concern and at present is a severe threat to the survival of living organisms, jeopardizing the ecological balance [15]. In the world literature, results for pollution of various types of water (surface waters, groundwater) in various areas are comparable [16-19].

Based on the data collected during investigations in 2008 and 2013, an attempt was made to assess if and to what degree nitrogen compounds $\left(\mathrm{NO}_{3}^{-}, \mathrm{NO}_{2}^{-}\right.$and $\mathrm{NH}_{4}^{+}$) and other selected general water quality indices affecting water quality in a water reservoir influenced the process of eutrophication of the investigated ecosystem.

\section{Material and Methods}

Warnowo Lake (Fig. 1; 5356,1'latitude and 14³2,8' longitude [20] is located on Wolin Island in the territory of Wolin National Park (WNP) in the Warnowo Protected Area, in the northeastern region of WNP between towns Międzyzdroje, Warnowo and Wisełka. To the south and east of this lake is the village of the same name.

Lake Warnowo is the first gutter lake of several lakes connected by Lewińska (Pojezierna) Stream in Wolin Island, which flows from Lake Warnowo through lakes Rabiąż, Czajcze, and Domysłowskie, and through other lakes of the Warnowsko-Kołczewskiego Lake District not lying on the territory of WNP, up to Kamieński Lagoon [21].

Water mirror of Lake Warnowo is located at an altitude of 1,4 $\mathrm{m}$ above sea level. The surface of this lake is $0,127 \mathrm{~km}^{2}$, the maximum depth is $2,1 \mathrm{~m}$, the average depth is about $1,3 \mathrm{~m}$, and volume is $160700 \mathrm{~m}^{3}$ $[20,22]$. Cryptodepression is small at $0.7 \mathrm{~m}$. The small surface and depth of this lake and the average wind hooding allow for constant mixing of waters to the bottom. In the eastern part, the reservoir is connected by a canal (mostly overgrown with water vegetation), which is the first section of Lewinska Struga with a depth of about $0,7 \mathrm{~m}$, a width of $3,5 \mathrm{~m}$ and a length of about $10 \mathrm{~m}$ - with Lake Rabiąż.

Water samples for investigation were collected [after 23] at the water measuring sampling station (Fig. 1) from the surface layer of Lake Warnowo from a depth of about $25 \mathrm{~cm}$ below the water surface. Water samples were collected in spring once a month on arbitrarily selected dates: 23.03., 17.04., 18.05, and 25.06 in the year 2008; and 16.03., 13.04., 11.05, and 15.06 in the year 2013. Temperature [24] and the $\mathrm{pH}$ of water [25] were determined at the place of sample

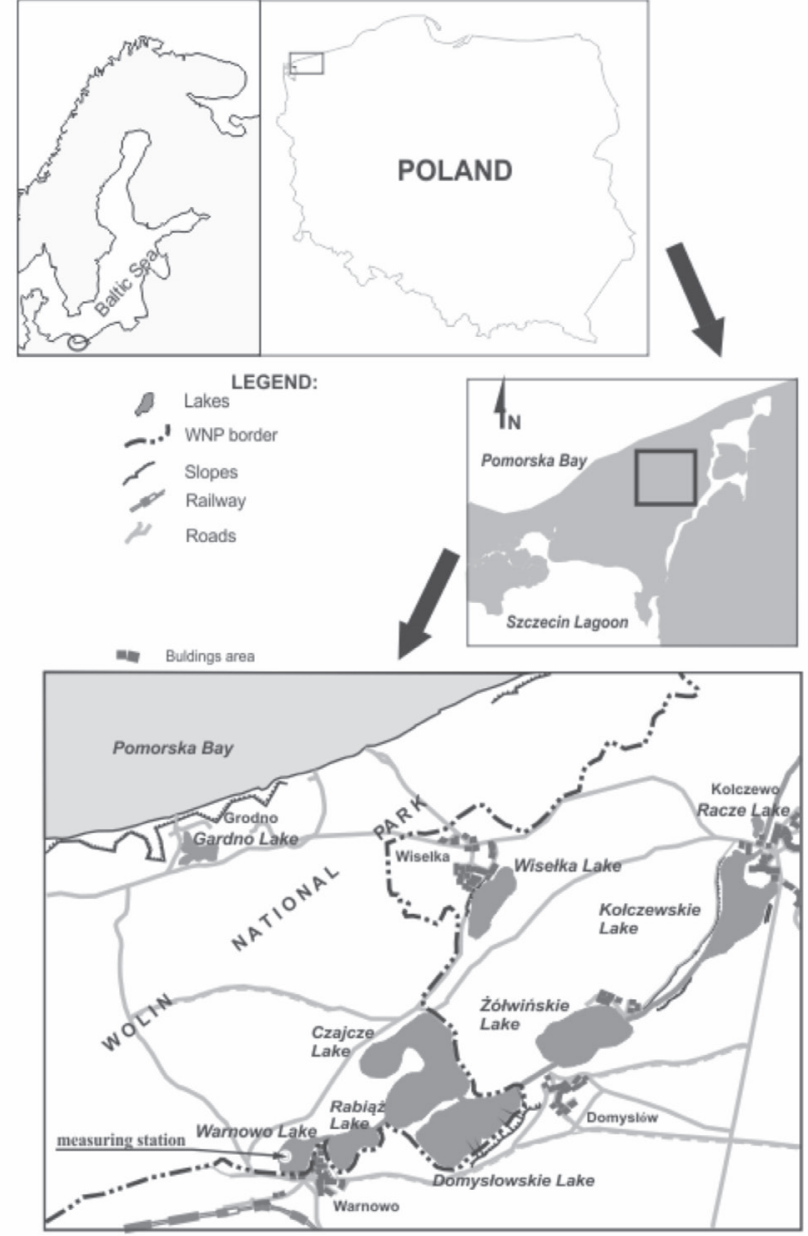

Fig. 1. Lake Warnowo's location in Wolin National Park and the measuring station location.

collection. Water samples were taken separately to determine dissolved oxygen concentration [26]. Water samples taken for determining concentrations of dissolved substances in laboratory analyses were fixed [27] at the place of sample collection. Water samples were investigated in the laboratory within 24 hours. Determined concentrations are COD-Mn, $\mathrm{NO}_{3}^{-}, \mathrm{NO}_{2}^{-}$, and $\mathrm{NH}_{4}^{+}$[26].

In order to determine which of the investigated water quality indices in Lake Warnowo had an impact on the eutrophication-investigated reservoir, the collected results of investigation were conducted with statistical analysis using the computer software Statistica.

\section{Results and Discussion}

The results of investigations of surface waters of Lake Warnowo in the place of the measuring station (Fig. 1) are presented in Tables 1-4 and Figs 2-4. Based on the analysis of collected data, a clear picture of the water quality of Lake Warnowo and changes of this water quality in years 2008 and 2013 were obtained. 
Table 1. Results of the investigation of chosen water quality indices of Lake Warnowo in spring 2008 and 2013.

\begin{tabular}{|c|c|c|c|c|c|c|c|c|c|}
\hline \multirow{3}{*}{ No. } & \multirow{3}{*}{ Indices (units) } & \multicolumn{8}{|c|}{ Date of water sampling in years } \\
\hline & & \multicolumn{4}{|c|}{ Year 2008} & \multicolumn{4}{|c|}{ Year 2013} \\
\hline & & 23.03 . & 17.04. & 18.05 . & 25.06 . & 16.03 . & 13.04. & $11.05 .$. & 15.06. \\
\hline 1 & $\mathrm{NO}_{3}^{-}\left(\mathrm{mg} \mathrm{N}-\mathrm{NO}_{3} \cdot \mathrm{dm}^{-3}\right)$ & 0,39 & 0,15 & 0,06 & 0,06 & 0,17 & 0,10 & 0,28 & 0,04 \\
\hline 2 & $\mathrm{NO}_{2}^{-}\left(\mathrm{mg} \mathrm{N}-\mathrm{NO}_{2} \cdot \mathrm{dm}^{-3}\right)$ & 0,016 & 0,014 & 0,005 & 0,012 & 0,001 & 0,103 & 0,003 & 0,024 \\
\hline 3 & $\mathrm{NH}_{4}^{+}\left(\mathrm{mg} \mathrm{N}-\mathrm{NH}_{4} \cdot \mathrm{dm}^{-3}\right)$ & 0,03 & 0,13 & 0,08 & 0,11 & 0,34 & 0,01 & 0,02 & 0,09 \\
\hline 4 & Temperature $\left({ }^{\circ} \mathrm{C}\right)$ & 6,0 & 10,0 & 15,0 & 21,0 & $-2,0$ & 5,0 & 19,5 & 23,3 \\
\hline 5 & pH (pH units) & 7,70 & 7,86 & 8,29 & 8,07 & 7,92 & 8,17 & 7,86 & 8,31 \\
\hline 6 & COD-Mn $\left(\mathrm{mg} \mathrm{O}_{2} \cdot \mathrm{dm}^{-3}\right)$ & 8,0 & 9,2 & 10,0 & 10,4 & 14,2 & 9,7 & 7,9 & 10,1 \\
\hline 7 & $\mathrm{O}_{2 \text { (diss.) }}\left(\mathrm{mg} \mathrm{O}_{2} \cdot \mathrm{dm}^{-3}\right)$ & 8,3 & 7,1 & 4,7 & 4,2 & 12,72 & 17,00 & 6,50 & 2,40 \\
\hline
\end{tabular}

Table 2. Statistical characteristics - minimal values (Min.), mean values (Mean), maximum values (Max.), standard error of estimation (SD) and standard deviation (CV) - of investigated water quality indices of Warnowo Lake in spring 2008 and 2013.

\begin{tabular}{|c|c|c|c|c|c|c|c|c|c|c|c|}
\hline \multirow{3}{*}{ No. } & \multirow{3}{*}{ Indices (units) } & \multicolumn{10}{|c|}{ Statistical characteristic } \\
\hline & & \multicolumn{5}{|c|}{ Year 2008} & \multicolumn{5}{|c|}{ Year 2013} \\
\hline & & Min. & Mean & Max. & SD & $\mathrm{CV}$ & Min. & Mean & Max. & $\mathrm{SD}$ & $\mathrm{CV}$ \\
\hline 1 & $\mathrm{NO}_{3}^{-}\left(\mathrm{mg} \mathrm{N}-\mathrm{NO}_{3} \cdot \mathrm{dm}^{-3}\right)$ & 0,06 & 0,17 & 0,39 & 0,16 & 0,94 & 0,04 & 0,15 & 0,28 & 0,10 & 0,70 \\
\hline 2 & $\mathrm{NO}_{2}^{-}\left(\mathrm{mg} \mathrm{N}-\mathrm{NO}_{2} \cdot \mathrm{dm}^{-3}\right)$ & 0,005 & 0,012 & 0,016 & 0,005 & 0,41 & 0,001 & 0,033 & 0,103 & 0,048 & 1,46 \\
\hline 3 & $\mathrm{NH}_{4}^{+}\left(\mathrm{mg} \mathrm{N}-\mathrm{NH}_{4} \cdot \mathrm{dm}^{-3}\right)$ & 0,03 & 0,09 & 0,13 & 0,04 & 0,50 & 0,01 & 0,12 & 0,34 & 0,15 & 1,34 \\
\hline 4 & Temperature $\left({ }^{\circ} \mathrm{C}\right)$ & 6,0 & 13,0 & 21,0 & 6,5 & 0,50 & $-2,0$ & 11,5 & 23,3 & 11,9 & 1,04 \\
\hline 5 & $\mathrm{pH}$ (pH units) & 7,70 & 7,98 & 8,29 & 0,26 & 0,03 & 7,86 & 8,07 & 8,31 & 0,21 & 0,03 \\
\hline 6 & COD-Mn $\left(\mathrm{mg} \mathrm{O}_{2} \cdot \mathrm{dm}^{-3}\right)$ & 8,0 & 9,4 & 10,4 & 1,1 & 0,11 & 7,9 & 10,5 & 14,2 & 2,7 & 0,25 \\
\hline 7 & $\mathrm{O}_{2 \text { (diss.) }}\left(\mathrm{mg} \mathrm{O}_{2} \cdot \mathrm{dm}^{-3}\right)$ & 4,20 & 6,08 & 8,30 & 1,95 & 0,32 & 2,4 & 9,66 & 17,00 & 6,48 & 0,67 \\
\hline
\end{tabular}

Table 3. Significant level of Pearson correlation between investigated water quality indices

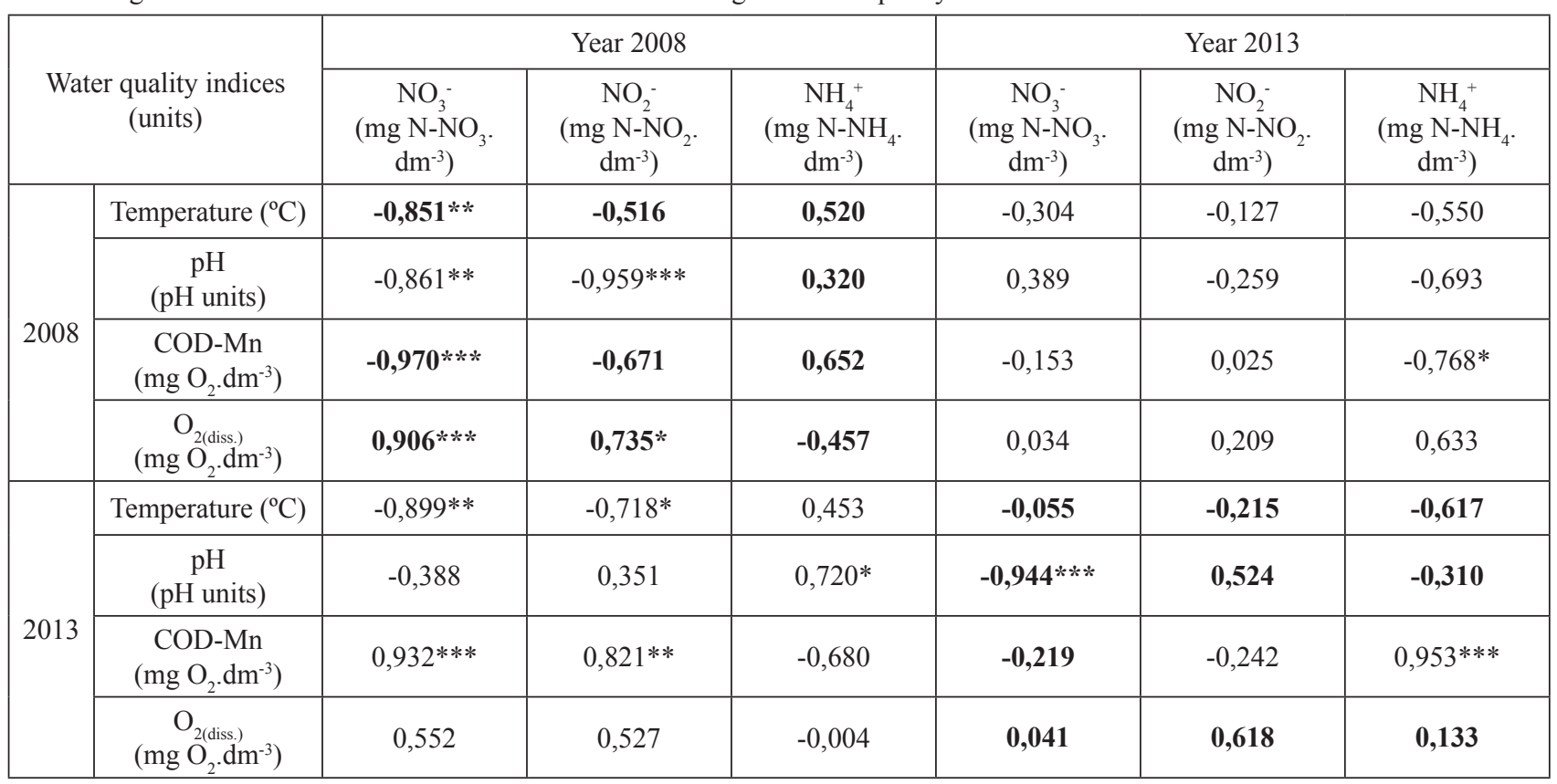

Significant level: *** $\alpha \leq 0,001, * * 0,001<\alpha \leq 0,01, * 0,01<\alpha \leq 0,05$ 
Table 4. PCA results - Eigenvalues of principal components of matrix correlation.

\begin{tabular}{|c|c|c|c|c|c|c|c|}
\hline \multirow{2}{*}{ No. } & \multirow{2}{*}{ Indices (units) } & \multicolumn{3}{|c|}{ Year 2008} & \multicolumn{3}{|c|}{ Year 2013} \\
\hline & & $\mathrm{PC} 1$ & PC2 & PC3 & PC1 & $\mathrm{PC} 2$ & PC3 \\
\hline 1 & $\mathrm{NO}_{3}^{-}\left(\mathrm{mg} \mathrm{N}-\mathrm{NO}_{3} \cdot \mathrm{dm}^{-3}\right)$ & $-0,990$ & 0,005 & 0,142 & 0,626 & 0,735 & 0,261 \\
\hline 2 & $\mathrm{NO}_{2}^{-}\left(\mathrm{mg} \mathrm{N}-\mathrm{NO}_{2} \cdot \mathrm{dm}^{-3}\right)$ & $-0,741$ & $-0,666$ & $-0,091$ & $-0,922$ & 0,000 & 0,387 \\
\hline 3 & $\mathrm{NH}_{4}{ }^{+}\left(\mathrm{mg} \mathrm{N}-\mathrm{NH}_{4} \cdot \mathrm{dm}^{-3}\right)$ & 0,763 & $-0,640$ & 0,096 & 0,680 & $-0,676$ & 0,284 \\
\hline 4 & Temperature $\quad\left({ }^{0} \mathrm{C}\right)$ & 0,768 & 0,007 & $-0,640$ & $-0,150$ & 0,378 & $-0,914$ \\
\hline 5 & $\mathrm{pH}$ (pH units) & 0,856 & 0,504 & $-0,114$ & $-0,754$ & $-0,486$ & $-0,442$ \\
\hline 6 & COD-Mn $\left(\mathrm{mg} \mathrm{O}_{2} \cdot \mathrm{dm}^{-3}\right)$ & 0,926 & 0,029 & $-0,376$ & 0,431 & $-0,808$ & 0,402 \\
\hline \multirow[t]{4}{*}{7} & $\mathrm{O}_{2 \text { (diss.) }}\left(\mathrm{mg} \mathrm{O}_{2} \cdot \mathrm{dm}^{-3}\right)$ & $-0,848$ & $-0,225$ & 0,479 & $-0,266$ & $-0,060$ & 0,962 \\
\hline & Eigenvalue & 2,110 & 0,852 & 0,038 & 1,704 & 0,997 & 299 \\
\hline & Variability $(\%)$ & 70,349 & 28,401 & 1,250 & 56,801 & 33,229 & 9,970 \\
\hline & Cumulative $\%$ & 70,349 & 98,750 & 100,000 & 56,801 & 90,030 & 100,000 \\
\hline
\end{tabular}

On the basis of the data presented in Tables 1 and 2, it was observed that the concentrations of $\mathrm{NO}_{3}{ }^{-}$in 2008 showed a downward trend during the research period, while in 2013 they showed periodic cyclical changes. In 2008 the concentration of $\mathrm{NO}_{3}^{-}$was significantly higher than in 2013. In turn, the concentrations of $\mathrm{NO}_{2}^{-}$and $\mathrm{NH}_{4}^{+}$in both years (2008 and 2013) showed regular cyclical changes, and their values in 2008 were significantly lower than in 2013.

With regard to additionally indicated water quality indices in this paper, the $\mathrm{pH}$ values of the surface waters of Lake Warnowo in both years (2008 and 2013) were very close to each other and amounted to about 7,70-8,30 pH units. On the other hand, water temperature in March and April 2008 was higher on average by about $6,5^{\circ} \mathrm{C}$ than in the same investigated period in 2013, while in May and June the water temperature was higher on average by about $4,0^{\circ} \mathrm{C}$ in 2013 than in 2008 . This shows a significantly greater variation in values of water temperature in 2013. The concentration values of $\mathrm{O}_{2 \text { (diss.) }}$ and COD-Mn in the investigated season of the year 2008 showed an upward trend, and in 2013 the situation was reversed.

For a more complete description of the experimental data presented in Tables 1 and 2, box-whisker diagrams were prepared to graphically illustrate some [28] selected statistical characteristics.

After [29], Pearson correlations, discriminant analysis and principal component analysis (PCA) were applied to assess the temporal variations in water quality indices and estimation of latent pollution factors in surface water of Lake Warnowo.

The experimental data were analyzed by principal components analysis (PCA) (Tables 3 and 4, Fig. 3). Also, dendrograms of the surface water quality indices of Lake Warnowo were performed by means of cluster analysis and Ward's method (Fig. 4). On the basis of results presented in Tables 3 and 4 and Figs. 3 and 4, an attempt was made to determine which of the additional water quality indices investigated in this work have the greatest effect on concentrations of $\mathrm{NO}_{3}^{-}, \mathrm{NO}_{2}^{-}$and $\mathrm{NH}_{4}^{+}$.
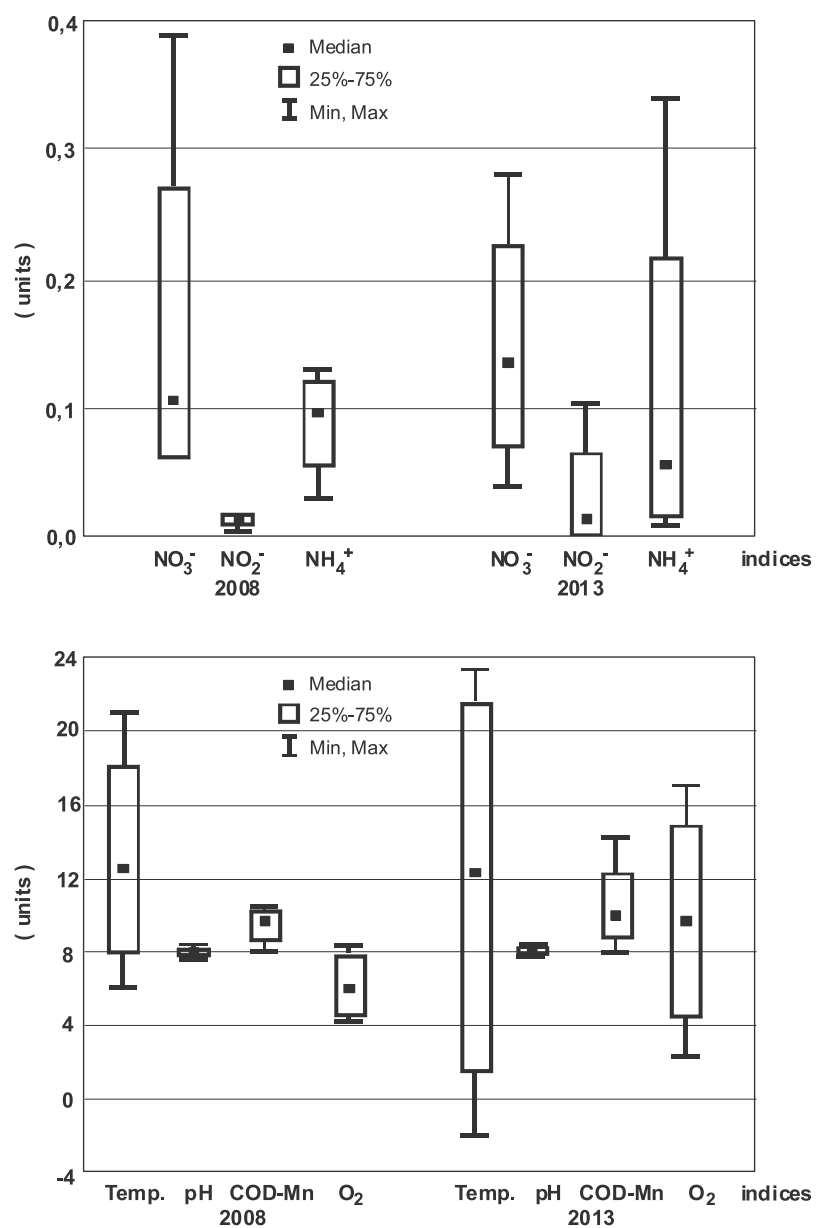

Fig. 2. Selected statistical characteristics of data set of investigated surface water quality indices of Lake Warnowo. 

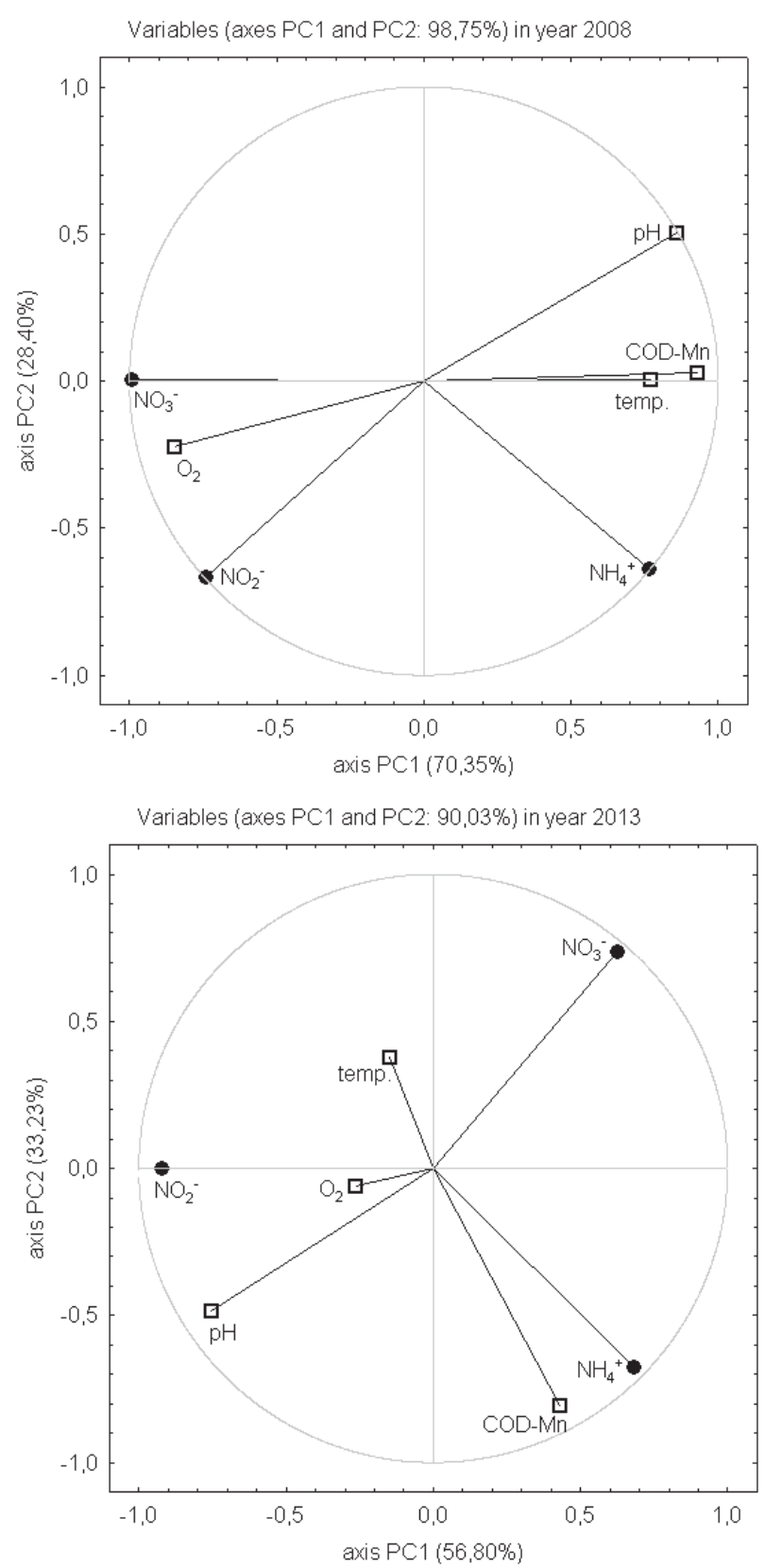

Fig. 3. PCA ordination diagrams of investigated water quality indices in 2008 and 2013.

PCA that represents the matrix correlation of water quality indices investigated in this work in 2008 and 2013 was used to identify independent factors explaining the spatial variability of concentrations of $\mathrm{NO}_{3}^{-}, \mathrm{NO}_{2}^{-}$and $\mathrm{NH}_{4}^{+}$. PCA was performed on the basis of normalized results of hydrochemical analyses. A similar approach to hydrochemical interpretation of water was presented by [30]. Table 3 presents the Pearson correlation coefficients describing the degree of dependence of individual water quality indices from each other in 2008 and 2013. Investigated water quality indices showed both positive and negative correlations. The greater the absolute value, the greater the correlation between the individual indicators.
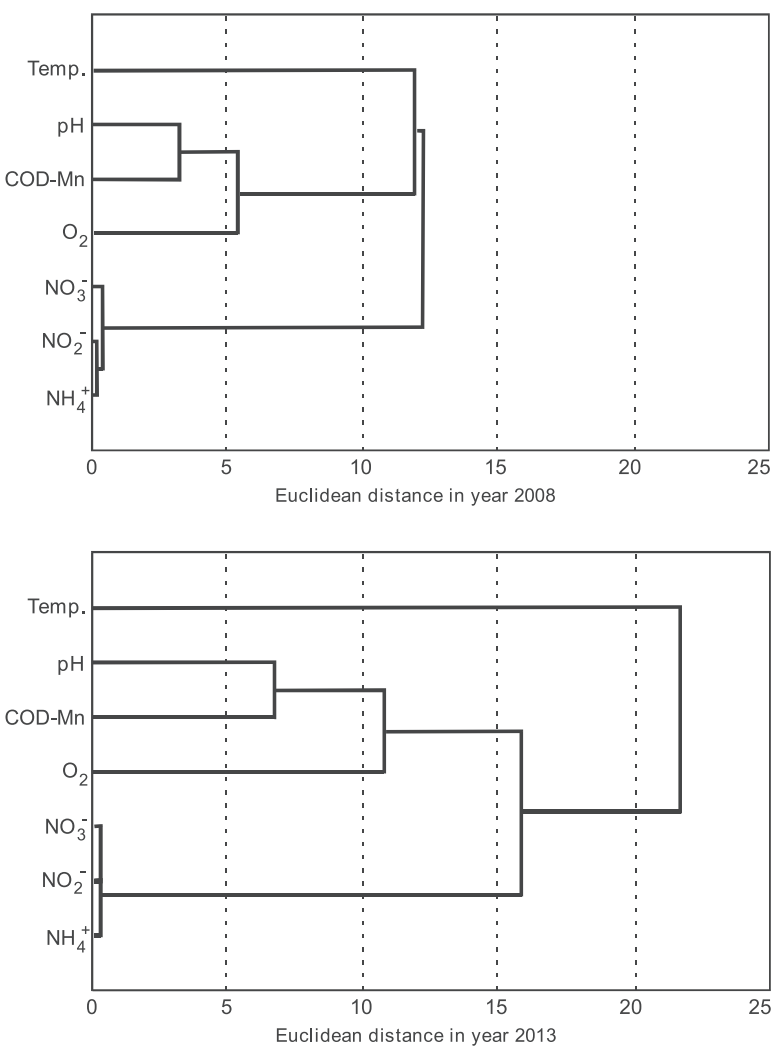

Fig. 4. Euclidean distance based on hierarchical dendrograms of investigated surface water quality indices in Lake Warnowo.

The analysis of the eigenvalues main components $>1$ PCA shows that the plane of the first and the second principal component (Tab. 4, Fig. 3) describes 98,75\% and $90,03 \%$ of the variance of the primary (original) data in years 2008 and 2013. According to the above criteria, only principal components (PCs) with values higher than the values of the principal components were considered [1, 31, 32].

The percentage explained by the first two dimensions is in both cases above $90 \%$, and as according to [33] it is very high. In literature it is assumed that if the percentage explained by the first two dimensions is above $70 \%$, it means that it is statistically significant $[34,35]$. Some of the authors say that if the percentage explained by the first two dimensions is $64 \%$, then it is also very significant statistically [e.g. 36].

The author of this work claims that the amount of data used in the analysis should be taken into consideration when giving the statistical significance of the percentage value of the variance of the original data. The smaller the set of data, the percentage explained by the first two dimensions should be higher.

Fig. 3 clearly shows which of the investigated water quality indices have a similar nature of change and which are clearly different from each other. Those of the water quality indices that had higher intrinsic values had the corresponding self-correlated vector values less correlated with the other parameters [37]. 
From the data presented in Table 4 and Fig. 3, it is clearly shown that in 2008 there were statistically significant correlations between $\mathrm{NO}_{3}^{-}$and COD-Mn (strong negative correlation), $\mathrm{NO}_{3}^{-}$and $\mathrm{O}_{2}$ (strong positive correlation), and $\mathrm{NO}_{2}^{-}$and $\mathrm{pH}$ (strong negative correlation), and also worse positive correlations between $\mathrm{NH}_{4}^{+}$and COD-Mn as well as between $\mathrm{NH}_{4}^{+}$ and temperature and negative correlations between $\mathrm{NO}_{3}^{-}$ and temperature, and between $\mathrm{NO}_{3}{ }^{-}$and $\mathrm{pH}$. In 2013 there were statistically significant correlations between $\mathrm{NO}_{3}{ }^{-}$and $\mathrm{pH}$ (strong negative correlation), and between $\mathrm{NH}_{4}^{+}$and COD-Mn (strong positive correlation). On the other hand, $\mathrm{NO}_{2}^{-}$showed worse positive correlations with $\mathrm{O}_{2}$ and $\mathrm{pH}$ of water.

The correlations presented graphically in Fig. 3 are very similar to the correlations between investigated water quality indices shown numerically in Table 3. A similar satisfactory optimization of results was also received by [38] in his research on the hydrological parameter classification. Ren et al. [38] modeled in his research on the studies of [39-42] showing that the values of parameters on PCA diagrams can be presented as correlation tables between investigated parameters.

Then, using the cluster analysis, hierarchical dendrograms of the surface water quality indices of Lake Warnowo were presented in Fig. 4. Water quality indices were grouped into indicators that provide the most and least information about the interactions between the examined indicators [28, 43]. The investigated results were grouped into two groups. The first group consisted of indices: $\mathrm{NO}_{3}^{-}, \mathrm{NO}_{2}^{-}$and $\mathrm{NH}_{4}^{+}$, while the other group had water temperature, $\mathrm{pH}$, COD-Mn and $\mathrm{O}_{2 \text { (diss.) }}$. In 2008 the highest influence on the concentration of nitrogen compounds and the nature of surface water in Lake Warnowo was $\mathrm{pH}$ of water and COD-Mn, followed by $\mathrm{O}_{2 \text { (diss.) }}$ and water temperature. In turn, in 2013 there wasn't a direct influence of temperature on the concentration of nitrogen compounds $\left(\mathrm{NO}_{3}^{-}, \mathrm{NO}_{2}^{-}\right.$and $\left.\mathrm{NH}_{4}^{+}\right)$in water. This shows that parameters that can be significant in contributing to water quality in one season may be less significant or not in the other season [44].

Generally, the analysis of the dendrograms presented in Fig. 4 shows that the $\mathrm{pH}$ of the tested waters and COD-Mn had the strongest influence on the presence of nitrogen compounds as ions of $\mathrm{NO}_{3}^{-}, \mathrm{NO}_{2}^{-}$ and $\mathrm{NH}_{4}^{+}$, while the lowest influence was seen by water temperature.

The results of the investigations (Fig. 4) presented as the hierarchical dendrograms, confirm and complement the results obtained by using the PCA method (Fig. 3, Tables 3 and 4). Similar results have been reported by [45] in his research on surface waters of the Ganjiang River (China), who used identical statistical methods for interpreting experimental data.

The methods presented in this work are welldeveloped and often used by researchers as statistical techniques to identify and pre-characterize the different groups of elements in waters that exhibit similar seasonal variability and correlations [14, 46-50]. In addition, this study demonstrates the usefulness of multivariate statistical techniques for the analysis and interpretation of experimental data, and also for a better understanding of seasonal variations (changes) in water quality $[1,51,52]$.

The content and seasonal variability of nitrogen compounds in the surface waters of Lake Warnowo undoubtedly depended on many factors [30]. The most important factors are the location of the lake, meteorological conditions [53] and hydrological conditions.

The highest concentrations of $\mathrm{NO}_{3}^{-}, \mathrm{NO}_{2}^{-}$and $\mathrm{NH}_{4}^{+}$ were noted in both 2008 and 2013 in early spring (March), and almost immediately after the end of freezing. Probably this was due to the period of winter stagnation of waters, the flow of melting waters from the area around the lake [21, 30], as well as reduced vegetation of aquatic organisms [54]. Between April and June, lower concentrations of $\mathrm{NO}_{3}{ }^{-}, \mathrm{NO}_{2}{ }^{-}$and $\mathrm{NH}_{4}^{+}$were noted, which was more likely related to the absorption of these biogenic compounds by aquatic organisms [14, 54, 55]. Nevertheless, the concentrations of $\mathrm{NO}_{3}^{-}$in 2008 were significantly higher than in 2013 , while the concentrations of $\mathrm{NO}_{2}^{-}$and $\mathrm{NH}_{4}^{+}$in 2008 were much lower than in 2013. Higher concentrations of $\mathrm{NH}_{4}^{+}$ in water samples taken for investigation, especially in 2013, at relatively lower $\mathrm{NO}_{2}^{-}$concentrations may indicate increased human activity [13, 56], and especially the "fresh" effluent of communal sewage [7, 8] coming from residential buildings adjacent to the lake near Warnowo. According to [12], the concentrations of investigated biogenic substances classified the waters of Lake Warnowo due to the concentration of $\mathrm{NO}_{3}{ }^{-}$- as non-class waters in 2008 and water class II in 2013, and due to the concentration of $\mathrm{NH}_{4}^{+}$- as water class I in 2008 and as non-class waters in 2013. Excess amounts of $\mathrm{NO}_{3}^{-}, \mathrm{NO}_{2}^{-}$and $\mathrm{NH}_{4}^{+}$compounds in water led to a high fertility of the lake's waters and caused a rapid and uncontrolled development of aquatic vegetation. This is confirmed by the $\mathrm{pH}$ values of the investigated waters as well as the low concentrations of oxygen in May and June in the lake ecosystem. It also confirms the high trophy of Lake Warnowo.

The high abundance of biogenic compounds in the lake is probably related to the location of the lake on earlier agricultural areas [57], now a large part of which is built up with households in Warnowo [6] and allotment gardens, which is probably the cause of additional continuous supply of the lake water with nitrogen compounds [9] in the form of various illegal pollutants discharged directly into the lake. Such additional "injection" of pollutants rich in $\mathrm{NO}_{3}^{-}, \mathrm{NO}_{2}^{-}$ and $\mathrm{NH}_{4}^{+}$significantly accelerate eutrophication $[10,11$, 58].

Such a load of water with biogenic substances is unfavorable because of the increase in water temperature. Water saturation by oxygen is lower and therefore the water self-purification capacity is lower in 
the summer than in the winter, as well as the increase in water stagnation meaning less dilution of pollutants in water [8].

The biological tests, especially short-term bioassays on bacteria or higher plants, is the best way to detect and estimate the pollution load in any matrices approach [15]. The tests in plants are relatively inexpensive, easy to use, and most importantly they are a rapid and sensitive method for environmental monitoring. Other short-term tests for monitoring water toxicity are the widely used vibrio fischeri bioluminescence inhibition bioassay (VFBIA) test [59].

Statistical analysis indicated in this paper showed statistically significant correlations between concentrations of biogenic substances and other investigated water quality indices, which were dependent among other things on lake location, meteorological and hydrological conditions [60, 61]. The above results undoubtedly show the dominance of these factors in shaping the abundance of lake waters into biogenic substances. As [61] suggests, the trophic state analysis of a lake should be repeated based on the collected data taking into account the local variation (changes) in water quality and external factors that disrupt the uniformity of hydrochemical conditions.

\section{Conclusions}

Based on the studies conducted in 2008 and 2013, it was found that in the waters of Lake Warnowo (Wolin National Park) in 2013 (as compared to 2008) saw an increase of $\mathrm{NO}_{2}^{-}$and $\mathrm{NH}_{4}^{+}$concentrations observed during the research period. This shows that, despite the advancement of civilization, there are still built-up areas with insufficient communal infrastructure in the 21 st century, as it was in the case of the investigated area. This resulted in an uncontrolled inflow of sewage to the waters of Lake Warnowo (most probably from households in Warnowo Village), which were very rich in nitrogen compounds and organic matter.

\section{Acknowledgements}

I am thankful to the management of Wolin National Park for giving permission for field research.

\section{Conflict of Interest}

The authors declare no conflict of interest.

\section{References}

1. GARIZI A.Z., SHEIKH V., SADODDIN A. Assessment of seasonal variations of chemical characteristics in surface water using multivariate statistical methods,
International Journal of Environmental Science and Technology, 8 (3), 581, 2011. DOI: 10.1007/BF03326244

2. KULIKOWSKA-KARPIŃSKA E., KŁUSEWICZ K. Evaluation of chemical pollution of artificial reservoir water in Siemianówka in the years 2007-2008. Ochrona Środowiska i Zasobów Naturalnych, 40, 497, 2009 [In Polish].

3. POLESZCZUK G., BUCIOR A., TOKARZ M., PIERWIENIECKI J. Trophic status of the Rusałka Lake in Szczecin in years 1999-2010. Acta Biologica, 19, 37, 2012.

4. SOROKOVIKOVA L.M., SINYUKOVICH V.N., TOMBERG I.V., MARINAITE I.I., KHODZHER T.V. Assessing the Water Quality in the Tributary Streams of Lake Baikal From Chemical Parameters. Geography and Natural Resources, 36 (1), 31, 2015. DOI: 10.1134/ S1875372815010059

5. NOWICKA E., POLESZCZUK G., BUCIOR A., WAWRZYNIAK W. Syrenie Stawy in Szczecin as sewage water retention tanks. Stud. Mater. Inst. Badań i Ekspertyz Nauk. (Gorzów Wlkp.), 23, Ser. Ekologia Pogranicza, 2, 452, 2005 [In Polish].

6. BUCIOR A., POLESZCZUK G. What happens in the waters of the Warnowo, Rabiąż, Czajcze and Domysłowskie lakes in the Wolin National Park during summer stagnation? Ecological Chemistry and Engineering, Seria A, 20 (1), 7, 2013. DOI: 10.2428/ecea.2013.20(01)001

7. SIWEK J.P., BIERNACKI W. Impact of sewage discharged from tourist hostels on the concentration of biogenic compounds in streams - receivers of this sewage in the Tatra National Park (years 2008-2009). Gospodarka Wodna, 7, 202, 2015 [In Polish].

8. SIWEK J.P., BIERNACKI W. Effect of tourism-generated wastewater on biogenic ions concentrations in stream water in Tatra National Park (Poland). Journal on Protected Mountain Areas Research, 8 (2), 43, 2016. DOI: 10.1553/ eco.mont-8-2s43

9. SUN B., ZHANG L., YANG L., ZHANG F., NORSE D., ZHU Z. Agricultural Non-Point Source Pollution in China: Causes and Mitigation Measures. AMBIO, 41 (4), 370, 2012. DOI: $10.1007 / \mathrm{s} 13280-012-0249-6$

10. XU Y., LI A.J., QIN J., LI Q., HO J.G., LI H. Seasonal patterns of water quality and phytoplankton dynamics in surface waters in Guangzhou and Foshan, China. Science of The Total Environment, 590-591, 361, 2017. DOI: https://doi.org/10.1016/j.scitotenv.2017.02.032

11. WIŚNIOWSKA-KIELIAN B., NIEMIEC M. Assessment of nitrate content in the waters of the Dunajec River. Annal. Univ. Mariae Curie-Skłodowska, Lublin-Polonia, Sectio E, LVI, 147, 2006 [In Polish].

12. Regulation of the Minister of the Environment, Dz.U. Nr 257, poz. 1545, 2011 [In Polish].

13. TANDYRAK R., PARSZUTO K., GROCHOWSKA J., Water Quality of Lake Ełk as a Factor Connected with Tourism, Leisure and Recreation on an Urban Area. Quaestiones Geographicae, 35 (3), 51, 2016. DOI: https:// doi.org/10.1515/quageo-2016-0026

14. MAO X., KUANG C., GU J., KOLDITZ O., CHEN K., ZHANG J., ZHANG W., ZHANG Y. Analysis of Chlorophyll- $a$ Correlation to Determine Nutrient Limitations in the Coastal Waters of the Bohai Sea, China. Journal of Coastal Research, 33 (2), 396, 2017. DOI: 10.2112/JCOASTRES-D-16-00023.1

15. IQBAL M., ABBAS M., NISAR J., NAZIR A., QAMAR A. Z. Bioassays based on higher plants as excellent dosimeters for ecotoxicity monitoring: A review. Chemistry International, 5 (1), 1, 2019. 
16. HASSEN E.B., ASMARE A.M. Predictive performance modeling of Habesha brewery wastewater treatment plant using artificial neural networks. Chemistry International, $5(1), 87,2019$.

17. IWUOHA G.N., AKINSEYE A. Toxicological symptoms and leachates quality in Elelenwo Rivers State, Nigeria. Chemistry International, 5 (3), 198, 2019. DOI: https://doi. org/10.5281/zenodo. 2064343

18. DEEBA F., ABBAS N., BUTT M.T., IRFAN M. Ground water quality of selected areas of Punjab and Sind Provinces, Pakistan: Chemical and microbiological aspects. Chemistry International, 5 (4), 241, 2019. DOI: https://doi.org/10.5281/zenodo. 2573563

19. MAJOLAGBE A.O., ADEYI A.A., OSIBANJO O., ADAMS A.O., OJURI. O.O. Pollution vulnerability and health risk assessment of groundwater around an engineering landfill in Lagos, Nigeria. Chemistry International, 3 (1), 58, 2017.

20. JAŃCZAK J. (ed.) Atlas of Polish lakes - volume II. Lakes of the catchment areas of the Przymorze rivers and the lower Vistula river basin. IMGW, Bogucki Wydawnictwo Naukowe, Poznań, 256, 1997. ISBN: 83-86001-43-7 [In Polish].

21. WAWRZYNIAK W., POLESZCZUK G., BUCIOR A., PIERWIENIECKI J., LASKOWSKI F., TYMANOWSKI Ł., GRYNFELDER K., RUTKOWSKA J. Surface waters of the Tarnowsko-Kołczewski Lake District lakes in the Wolin National Park - trophic status in spring 2012. W: Zaborowski T (red.), Satori w publicznym bezpieczeństwie. Wyd. Inst. Badań i Ekspertyz Nauk. w Gorzowie Wlkp., Gorzów Wlkp.-Poznań, 350, 2012 [In Polish].

22. SZWARC M. General information about the Warnowo Conservation District, Wolin National Park, 2008. http:// www.wolinpn.pl/index.php?page $=32 \&$ artykul $=53 \quad[$ [n Polish].

23. ISO 5667-4:2016. Water quality -- Sampling -- Part 4: Guidance on sampling from lakes, natural and man-made.

24. HERMANOWICZ W., DOJLIDO J., DOŻAŃSKA W., KOZIOROWSKI B., ZERBE J. Physico-chemical investigating of water and sewage. Wyd. Arkady, 555, 1999 [In Polish].

25. PN-EN ISO 10523:2012 E. Water quality - Determination of $\mathrm{pH}$.

26. APHA. Standard methods for the examination of water and wastewater. $21^{\text {st }}$ ed. Washington, D.C.: APHA, 1368, 2005.

27. ISO 5667-3:2012. Water quality - Sampling - Part 3: Preservation and handling of water samples.

28. SINGH K.P., MALIK A.,MOHAN D.,SINHA S. Multivariate statistical techniques for the evaluation of spatial and temporal variations in water quality of Gomti River (India) - a case study. Water Research, 38 (18), 3980, 2004. DOI: http://dx.doi.org/10.1016/j.watres.2004.06.011

29. CHEN J., LI F., FAN Z., WANG Y. Integrated Application of Multivariate Statistical Methods to Source Apportionment of Watercourses in the Liao River Basin, Northeast China. International Journal of Environmental Research and Public Health, 13 (10), 1035, 2016. DOI: 10.3390/ijerph13101035

30. SIWEK J., RZONCA B., JAŚKOWIEC B., PLENZLER J., PŁACZKOWSKA E. Natural factors affecting the chemical composition of water in the catchment of Wołosatka Stream (High Bieszczady Mts.). In: Kozak J., Ostapowicz K., Bytnerowicz A., Wyżga B. (eds.), The Carpathians: integrating nature and society towards sustainability, Berlin, Heidelberg, 151, 2013.
31. KOWALKOWSKI T., ZBYTNIEWSKI R., SZPEJNA J., BUSZEWSKI B. Application of chemometrics in river water classification. Water Research, 40 (4), 744, 2006. DOI: 10.1016/j.watres.2005.11.042

32. KANNEL P.R., LEE S., KANEL S.R., KHAN S.P. Chemometric application in classification and assesment of monitoring locations of an urban river system. Analytica Chemica Acta, 582 (2), 390, 2007. DOI: 10.1016/j. aca.2006.09.006

33. JOSSE J., HUSSON F. Handling missing values in exploratory multivariate data analysis methods. Journal de la Société Française de Statistique, 153 (2), 79, 2012.

34. CRUZ A.G., CADENA R.S., ALVARO M.B.V.B., SANT'ANA A.S., OLIVEIRA C.A.F., FARIA J.A.F., BOLINI H.M.A., FERREIRA M.M.C. Assessing the use of different chemometric techniques to discriminate low-fat and full-fat yogurts. LWT - Food Science and Technology, 50, 210, 2013. http://dx.doi.org/10.1016/j. lwt.2012.05.023

35. UKALSKI K., ŚMIAŁOWSKI T. Multi-functional analysis of the results of preliminary experiments with winter rye. Biul. IHAR, 260/261, 251, 2011 [In Polish].

36. HOWANIEC N., SMOLIŃSKI A. Influence of fuel blend ash components on stream co-gasification of coal and biomass - Chemometric study. Energy, 78, 814, 2014. DOI: https://doi.org/10.1016/j.energy.2014.10.076

37. SMOLIŃSKI A., DROBEK L., DOMBEK V., BĄK A. Modeling of experimental data on trace elements and organic compounds content in industrial waste dumps. Chemosphere, 162, 189, 2016. DOI: https://doi. org/10.1016/j.chemosphere.2016.07.086

38. REN H., HOU Z., HUANG M., BAO J., SUN Y., TESFA T., LEUNG L.R. Classification of hydrological parameter sensitivity and evaluation of parameter transferability across 431 US MOPEX basins. Journal of Hydrology, 536, 92, 2016. DOI: https://doi.org/10.1016/j.jhydrol.2016.02.042

39. HOU Z., HUANG M., LEUNG L.R., LIN G., RICCIUTO D.M. Sensitivity of surface flux simulations to hydrologic parameters based on an uncertainty quantification framework applied to the Community Land Model. Journal of Geophysical Research, 117 (15), D15108, 2012. DOI: 10.1029/2012JD017521

40. BAO J., HOU Z., HUANG M., LIU Y. On approaches to analyze the sensitivity of simulated hydrologic fluxes to model parameters in the community land model. Water, 7, 6810, 2015. DOI: http://dx.doi.org/10.3390/w7126662

41. GONG W., DUAN Q., LI J., WANG C., DI Z., DAI Y., YE A., MIAO C. Multi-objective parameter optimization of common land model using adaptive surrogate modeling. Hydrology and Earth System Sciences, 19 (5), $2409,2015$. DOI: 10.5194/hess-19-2409-2015

42. RAY J., HOU Z., HUANG M., SARGSYAN K., SWILER L. Bayesian calibration of the Community Land Model using surrogates, SIAM/ASA J. Uncertainty Quantification, 3 (1), 199, 2015. DOI: http://dx.doi. org/10.1137/140957998

43. VEGA M., PARDO R., BARRADO E., DEBAN L. Assessment of seasonal and polluting effects on the quality of river water by exploratory data analysis, Water Research, 32 (12), 3581, 1998. DOI: http://dx.doi. org/10.1016/S0043-1354(98)00138-9

44. OKETOLA A.A., ADEKOLUREJO S.M., OSIBANJO O. Water quality assessment of river Ogun using multivariate statistical techniques. Journal of Environmental Protection, 4, 466, 2013. DOI: http:// dx.doi.org/10.4236/jep.2013.45055 
45. ZHANG H., JIANG Y., WANG M., WANG P., SHI G., DING M. Spatial characterization, risk assessment, and statistical source identification of the dissolved trace elements in the Ganjiang River-feeding tributary of the Poyang Lake, China. Environmental Science and Pollution Research, 24 (3), 2890, 2017. DOI: 10.1007/ s11356-016-7988-z

46. VAROL M., GÖKOT B., BEKLEYEN A., ŞEN B. Water quality assessment and apportionment of pollution sources of Tigris River (Turkey) using multivariate statistical techniques - a case study. River Research and Applications, 28 (9):1428, 2012. DOI: 10.1002/rra.1533

47. SHIN J.Y., ARTIGAS F., HOBBLE C., LEE Y.S. Assessment of anthropogenic influences on surface water quality in urban estuary northern New Jersey: multivariate approach. Environmental Monitoring and Assessment, 185 (3), 2777, 2013. DOI: 10.1007/s10661012-2748-0

48. GIRI S., SINGH A.K. Risk assessment, statistical source identification and seasonal fluctuation of dissolved metals in the Subarnarekha River, India. Journal of Hazardous Materials, 265, 305, 2014. DOI: https://doi. org/10.1016/j.jhazmat.2013.09.067

49. KRISHNA A.K., MOHAN K.R. Risk assessment of heavy metals and their source distribution in waters of a contaminated industrial site. Environmental Science and Pollution Research, 21, 3653, 2014. DOI: 10.1007/ s11356-013-2359-5

50. BU H., WANG W., SONG X.F., ZHANG Q. Characteristics and source identification of dissolved trace elements in the Jinshui River of the South Qinling Mts., China. Environmental Science and Pollution Research, 22, 14248, 2015. DOI: 10.1007/s11356-0154650-0

51. ARSLAN H. Application of multivariate statistical techniques in the assessment of groundwater quality in seawater intrusion area in Bafra Plain, Turkey. Environmental Monitoring and Assessment, 185 (3), 2439, 2013. DOI: $10.1007 / \mathrm{s} 10661-012-2722-\mathrm{x}$

52. AKSEVER F., BÜYÜKŞAHIN S. Assessment of variations in water quality using statistical techniques: a case study of Işıklı Lake, Çivril/Denizli, Turkey. Arabian Journal of Geosciences, 10, 143, 2017. DOI: $10.1007 / \mathrm{s} 12517-017-2877-4$
53. RAFAŁOWSKA M. Assessment of nitrate content in surface waters of the area particularly at risk of pollution from agricultural sources. Proceedings of ECOpole, 2 (2), 473, 2008 [In Polish].

54. DOJLIDO J. R. Surface water chemistry. Wyd. Ekonomia i Środowisko, Białystok, 342, 1995 [In Polish].

55. KANOWNIK W., POLICHT-LATAWIEC A. Changeability of Oxygen and Biogenic Indices in Waters Flowing through Areas under Various Anthropopressures. Polish Journal of Environmental Studies, 24 (4), 1633, 2015. DOI: $10.15244 /$ pjoes/26486

56. SCHWEIGER A. H., BEIERKUHNLEIN C. The ecological legacy of 20th century acidification carried on by ecosystem engineers. Applied Vegetation Science, 20, 215, 2017. DOI: 10.1111 /avsc. 12259

57. CZYŻYK F., RAJMUND A. Penetration of nitrogen into the aquatic environment due to fertilization of light soil. Inżynieria Ekologiczna, 33, 29, 2013 [In Polish].

58. YAO L., JIANG X., CHEN C., LIU G., LIU W. Withinlake variability and environmental controls of sediment denitrification and associated $\mathrm{N}_{2} \mathrm{O}$ production in a shallow eutrophic lake. Ecological Engineering, 97, 251, 2016. DOI: https://doi.org/10.1016/j.ecoleng.2016.10.023

59. ABBAS M., ADIL M., EHTISHAM-UL-HAQUE S., MUNIR B., YAMEEN M., GHAFFAR A., SHAR G. A., ASIF T. M., IQBAL M. Vibriofischeribioluminescence inhibition assay for ecotoxicityassessment: A review. Science of The Total Environment, 626 (1), 1295, 2018. DOI: https://doi.org/10.1016/j.scitotenv.2018.01.066

60. KRAJEWSKA Z., FAC-BENEDA J. Transport of biogenic substances in watercourses of Coastal Landscape Park. Journal of Elementology, 21 (2), 413, 2016. DOI: 10.5601/ jelem.2015.20.1.800

61. LOPATA M., POLIELARCZYK D., TEMPLIN T. Changes of water quality of Lake Hańcza - are the water resources of the deepest lake of the central part of eutropean depression threatened? In: Water, Resources, Forest, Marine and Ocean Ecosystems Conference Proceedings, Vol. I, International Multidisciplinary Scientific GeoConference-SGEM, 137-144, 2016. 
